\title{
Field Response of Peas to Excess Heat during the Reproductive Stage of Growth
}

\author{
Floyd V. Pumphrey \\ Columbia Basin Agricultural Research Center, Oregon State University, Pendleton, OR 97801 \\ Robert E. Ramig \\ U.S. Department of Agriculture, Agricultural Research Service, Columbia Plateau Conservation \\ Research Center, P. O. Box 370, Pendleton, OR 97801
}

Additional index words. Pisum sativum, fresh peas, maximum daily temperatures, heat stress, exponentially adverse effect

\begin{abstract}
Regression analysis was used to establish the effect of maximum daily temperatures on fresh pea (Pisum sativum L.) yield during the reproductive stage of growth. Maximum daily temperatures below 25.6C had little influence on pea yield. Temperatures above $25.6 \mathrm{C}$ depressed yield; this adverse effect increased exponentially as maximum daily temperature increased linearly. Predicted decrease in fresh pea yield ranged from $16 \mathrm{~kg} / \mathrm{ha}$ per heat degree day above $27 \mathrm{C}$ to $67 \mathrm{~kg} / \mathrm{ha}$ per heat degree day above $35 \mathrm{C}$.
\end{abstract}

Literature describing the relationship between pea production and air temperature during the later stages of growth is relatively consistent on two points. The most critical time when high temperatures adversely affect pea yield is from flowering through pod filling (Boswell, 1929; Karr et al., 1959; Lambert and Linck, 1958; McWilliams, 1980; Stanfield et al., 1966). These authors also agree that the yield component primarily affected by temperatures above the optimum is reduction in the number of pods per plant.

Information available on heat-pea yield relationships is confusing as to the upper. optimum temperature. Lambert and Linck (1958) and Nonnecke et al. (1971) suggested 27C as a critical level for maximum daily temperatures $\left(\mathrm{dt}_{\max }\right)$. Wang (1962) gave 25 to $26 \mathrm{C}$ as an upper optimum during blooming and $36 \mathrm{C}$ as the upper threshold where growth ceased. A seasonal mean maximum of 20 to $21 \mathrm{C}$ was considered optimum for peas by Fletcher et al. (1966). Bowell (1929) concluded a daily mean of $20 \mathrm{C}$ to be near the critical heat point, with higher temperatures being adverse to pea growth. Stanfield et al. (1966) reported pea yields decreased as day temperatures increased above 16C and night temperatures increased above 10C. Wang (1962) attributed $75 \%$ of the yearly pea yield variations in Wisconsin to the difference in minimum temperatures during the seedling stage and the reproductive stage of growth. Warm springs and cool summers produced higher yields; cool springs and warm summers produced lower yields. Ridge and Rye (1985) stated that frosts near first bloom and high temperatures during flowering explained $68 \%$ of the variation in seed yield of peas near Horsham, Australia. They concluded that a $1 \mathrm{C}$ lowering of mean daily temperature during flowering should increase yield by 600 $\mathrm{kg} \cdot \mathrm{ha}^{-1}$. A review of the literature does not reveal information on the extent of yield reduction resulting from different temperature levels above the optimum.

Air temperatures vary considerably from day-to-day and yearto-year in the pea-growing area of northeastern Oregon, southeastern Washington, and northern Idaho (NOAA, 1944-1977).

Received for publication 5 Mar. 1990. Contribution from the Oregon Agricultural Experiment Station in cooperation with the Agricultural Research Service, USDA. Oregon Agr. Expt. Sta. Tech. Paper no. 4767. Appreciation is given to F. Ball, Kohler Betts, W. DeWitt (deceased), L.G. Ekin, T.R. Horning (deceased), M.M. Oveson (deceased), and H.M. Waddoups, who also collected data analyzed in this study. The cost of publishing this paper was defrayed in part by the payment of page charges. Under postal regulations, this paper therefore must be hereby marked advertisement solely to indicate this fact.
In some years, $\mathrm{dt}_{\max }$ for short periods during blooming and pod filling (mid-May into July) greatly exceed the suggested optimum temperature. These high temperatures are observed to stress the pea plant and to be adverse to pea yields.

Step-wise multiple regression analysis of yields of fresh peas, precipitation, and temperatures indicated that precipitation and $\mathrm{dt}_{\text {max }}$ above $26 \mathrm{C}$ from flower initiation to harvest accounted for $65 \%$ of the year-to-year variation in pea yields (Pumphrey et al., 1979). We analyzed air temperatures and pea yield data to determine the influence of $\mathrm{dt}_{\max }$ above 10 base temperatures on fresh pea yields.

\section{Materials and Methods}

Data for this study were compiled from 62 location-years of weather records and fresh pea yields near Pendleton, Ore. Measurements were made from 1945 through 1977, except in 1947 and 1966, when late spring frosts severely damaged the pea plants.

Peas were grown in a rotation of peas and winter wheat and were planted between 1 and 15 Apr. Blooming started after 10 May; harvest was generally in the last half of June but occasionally as late as early July. The pea cultivar grown was 'Dark Skinned Perfection', except for a few early years, when the cultivar Perfection was grown.

Maximum daily air temperatures were recorded at the Columbia Basin Agricultural Research Center, Pendleton. The farthest field location from the temperature observations was $16 \mathrm{~km}$. The range in elevation among all locations did not exceed 150 m.

Pea yields were adjusted to mean October through June precipitation to remove variation on yield due to year-to-year variability in water supply (Snedecor and Cochran, 1967). This allowed the effect of excess heat to be analyzed per se. Adjusted mean yield was $2615 \pm 880 \mathrm{~kg} \cdot \mathrm{ha}^{-1}$; range of yields was 400 to $4600 \mathrm{~kg} \cdot \mathrm{ha}^{-1}$.

Heat stress degree-day sums (HSDDS) were calculated from before bloom initiation to harvest for fresh peas, which was the reproductive growth stage. An HSDDS for each base temperature and location year was obtained as:

$$
\operatorname{HSDDS}=\sum_{\mathrm{i}=1}^{\mathrm{n}}\left(\mathrm{T}_{\mathrm{i}}-\mathrm{B}\right),
$$

where: i indexes each day from 10 May (before bloom initiation) 
to harvest for fresh peas; $\mathrm{n}$ is the number of days from 10 May to harvest; $\mathrm{T}_{\mathrm{i}}$ is $\mathrm{dt}_{\max }$ in ${ }^{\circ} \mathrm{C}$ measured in a standard weather instrument shelter; and $\mathrm{B}$ is a base temperature. Only positive values of $\left(T_{i}-B\right)$ were summed.

HSDDS were calculated for each of 10 base temperatures$20.6,22.2,23.9,25.6,27.2,28.9,30.6,32.2,33.9$, and $35.6 \mathrm{C}$ $(69,72,75,81,84,87,90,93$, and 96F)-for each location year. Simple regression analysis was used to obtain a regression equation expressing the relationship between the HSDDS above each base temperature and fresh pea yields. The model used w a s :

$$
\hat{\mathrm{y}}=\mathrm{a} ? \mathrm{~b} \mathrm{x},
$$

where: $\hat{y}$ is the estimated yield of fresh peas; a is the intercept; $\mathrm{b}$ is the regression coefficient; and $\mathrm{x}$ is the heat stress degree day sum (HSDDS). The regression coefficients from the 10 regression equations calculated using Eq. [2] were fit to the exponential equation $\hat{y}_{\mathrm{d}}=\mathrm{a}_{\mathrm{d}} \mathrm{x} \mathrm{e}^{\mathrm{bdx}}$ to describe the effect of increasing heat during the reproductive stage of growth on yield of fresh peas, where: $\hat{y}_{d}$ is estimated yield depression from $\mathrm{dt}_{\text {max }}$ above the base temperature; ad is the intercept; e is the base of natural $\log ; b_{d}$ is the regression coefficient; and $x$ is the HSDDS above the temperature base.

\section{Results and Discussion}

Heat stress degree day sums. Mean HSDDS declined as base temperatures increased (Table 1), indicating that many $\mathrm{dt}_{\max }$ exceeded the lower base temperature and few $\mathrm{dt}_{\max }$ exceeded the higher base temperatures. The ranges and standard deviations of the HSDDS express the variability in $\mathrm{dt}_{\max }$ during the reproductive stage of growth between years. Maximum daily temperatures considered to be adversely warm for pea production $(>25.6 \mathrm{C})$ occurred in all years.

Optimum temperature. The negative regression coefficients (Table 2), which are an expression of the influence of the average heat stress degree day above the base temperature on yield of fresh peas, became progressively larger with each increase in the base temperature. All were significant at $P=0.01$. The small changes in the size of the regression coefficients from base temperatures 20.6 through $25.6 \mathrm{C}$ indicate minimal adverse effect on pea yield of $\mathrm{dt}_{\max }$ slightly exceeding these lower base temperatures (Table 1). Further raising the base temperature increased the regression coefficients exponentially, showing the greater expression of the higher $\mathrm{dt}_{\max }$ on yield reduction.

The decline in intercepts as the base temperatures increased

Table 1. Means, ranges, and standard deviations of heat stress degree-day sums above 10 base temperatures in northeastern Oregon, 1945-1977.'

\begin{tabular}{cccc}
\hline \hline $\begin{array}{c}\text { Base temp } \\
\left({ }^{\circ} \mathrm{C}\right)\end{array}$ & \multicolumn{3}{c}{ Heat stress degree-day sums } \\
\cline { 2 - 4 } & Mean & Range & SD \\
\hline 20.6 & 253 & $124-398$ & 64 \\
22.2 & 194 & $82-321$ & 57 \\
23.9 & 140 & $50-244$ & 48 \\
25.6 & 96 & $30-186$ & 41 \\
27.2 & 64 & $16-137$ & 33 \\
28.9 & 39 & $3-105$ & 25 \\
30.6 & 22 & $1-77$ & 18 \\
32.2 & 11 & $0-53$ & 13 \\
33.9 & 5 & $0-33$ & 8 \\
35.6 & 2 & $0-16$ & 4 \\
\hline
\end{tabular}

z1947 and 1966 not included due to freezes.
Table 2. Regression equations for yields of fresh peas (adjusted to mean precipitation) vs. excess heat $(\mathrm{x}=$ heat stress degree-day sums) above base temperatures and standard deviations of regression coefficients, 1945-1977.'

\begin{tabular}{ccc}
\hline \hline $\begin{array}{c}\text { Base temp } \\
\left({ }^{\circ} \mathrm{C}\right)\end{array}$ & $\begin{array}{c}\text { Regression } \\
\text { equation } \\
\left(\mathrm{kg} \cdot \mathrm{ha}^{-1}\right)\end{array}$ & $\begin{array}{c}\text { Standard } \\
\text { deviation of } \\
\text { regression } \\
\text { coefficient }\end{array}$ \\
\hline 20.6 & $4095-5.85 \mathrm{x}$ & 1.60 \\
22.2 & $3961-6.94 \mathrm{x}$ & 1.76 \\
23.9 & $3878-9.01 \mathrm{x}$ & 2.03 \\
25.6 & $3743-11.7 \mathrm{x}$ & 2.31 \\
27.2 & $3599-15.3 \mathrm{x}$ & 2.87 \\
28.9 & $3428-20.8 \mathrm{x}$ & 3.66 \\
30.6 & $3242-29.1 \mathrm{x}$ & 4.94 \\
32.2 & $3084-40.9 \mathrm{x}$ & 7.59 \\
33.9 & $2928-61.6 \mathrm{x}$ & 12.42 \\
35.6 & $2347-76.4 \mathrm{x}$ & 24.45 \\
\hline
\end{tabular}

${ }^{z} 1947$ and 1966 not included due to freezes,

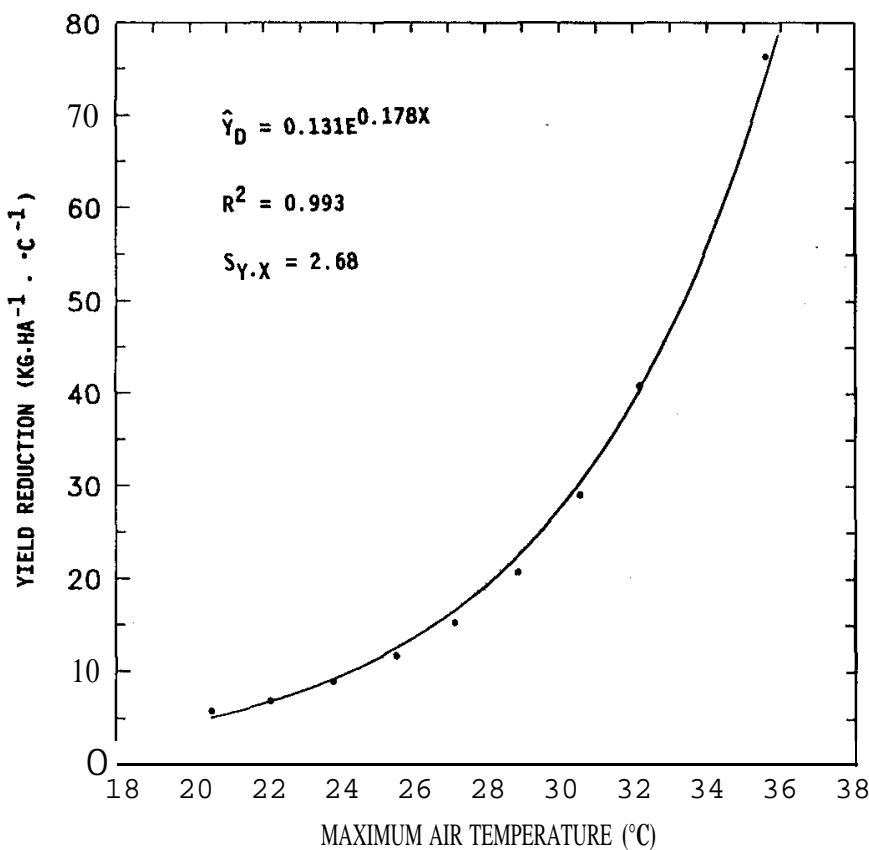

Fig. 1. Reduction in fresh pea yield $\left(\mathrm{kg} \cdot \mathrm{ha}^{-1}\right)$ from an average heat stress degree day above the base temperature during the reproductive stage of growth.

above $25.6 C$ and the rapid increase in the size of the regression coefficients with temperatures above 25.6C (Table 2) indicate the temperature level at which $\mathrm{dt}_{\max }$ became unfavorable for peas. There was little effect between 20.5 and $26 \mathrm{C}$ on yield, so that this broad range can be considered the upper temperature optimum. This result concurs with the findings of Wang (1960), who suggested an upper maximum range of 25 to $26 \mathrm{C}$.

Critical temperature. Regression coefficients (Table 2) increased rapidly when the base temperature was higher than $27.2 \mathrm{C}$. Regression coefficients plotted against base temperatures (Fig. 1) show the exponentially adverse effect of high temperatures during the reproductive growth period on fresh pea yields. Excellent fit of the data to the exponential equation is indicated by the large $r^{2}$ and the small error of estimate. The critical level of $\mathrm{dt}_{\max }$ of $27 \mathrm{C}$ suggested by Lambert and Linck (1958) and Nonnecke et al. (1971) is supported. 
The significant finding of the analysis reported in this paper is the exponentially increasing adverse effect on fresh pea yield of a linear increase in $\mathrm{dt}_{\max }$ above that of the optimum temperature range for pea reproduction. A strong negative correlation of heat degree-day sum and pea yield reported by Pumphrey et al. (1979) showed that peas were sensitive to and adversely affected by air temperatures above $25.6 \mathrm{C}$ during blooming and pod filling. The predicted linear effect on yield was $-12.9 \mathrm{~kg} /$ ha per heat degree day of temperature higher than $25.6 \mathrm{C}$. The exponentially adverse effect of excess heat on the yield of fresh peas in this study ranged from $-16.6 \mathrm{~kg} / \mathrm{ha}$ per heat degree day of air temperature above $27.2 \mathrm{C}$ to $-74.0 \mathrm{~kg} / \mathrm{ha}$ per heat degree day of air temperature above $35.6 \mathrm{C}$ during blooming and pod filling (Fig. 1). These data are in agreement with peas being $\mathrm{C}_{3}$ plants; increasing temperature above the optimum increases photorespiration (Fritter and Hay, 1981; McWilliams, 1980) and, thus, explains the increasing negative effect as $\mathrm{dt}_{\max }$ increased above $26 \mathrm{C}$.

This information should encourage pea producers to grow early maturing cultivars and to use the earlier, lower temperatures of the growing season where late pea-growing-season temperatures exceed 26C. Processors can use this model to estimate crop yields using weather records. These data aid in interpreting variations among years in research results attributable to $\mathrm{dt}_{\max }$ during flowering and pod filling.

\section{Literature Cited}

Boswell, V.R. 1929. Factors influencing yield and quality of peasBiophysical and biochemical studies. Maryland Agr. Expt. Sta. Bul. 306:341-392.

Fletcher, H. F., D.P. Ormrod, A.R. Maurer, and B. Stanfield. 1966.
Response of peas to environment. I. Planting date and location. Can. J. Plant Sci. 46:77-85.

Fritter, A.H. and R.K.M. Hay. 1981. Environmental physiology of plants. Academic, London. p. 59-64.

Karr, E. J., A.J. Linck, and C.A. Swanson. 1959. The effect of short periods of high temperature during day and night periods on pea yields. Amer. J. Bet. 46:91-93.

Lambert, R.G. and A.J. Linck. 1958. Effects of high temperature on yield of peas. Plant Physiol. 33:347-350.

McWilliams, J.R. 1980. Adaptation of plants to water and high temperature stress: Summary and synthesis-adaptation to high temperature stress, p. 444-477. In: N.C. Turner and P.J. Kramer (eds. ). Adaptation of plants to water and high temperature stress. Wiley, New York.

National Oceanic and Atmospheric Administration. 1944-1977 (inclusive). Climatological data, Idaho, Oregon, Washington (monthly). Natl. Climatic Ctr., Ashville, N.C.

Nonnecke, I. L., N.O. Adedipe, and D.P. Ormrod. 1971. Temperature and humidity effects on the growth and yield of pea cultivars. Can. J. Plant Sci. 51:479-484.

Pumphrey, F. V., R.E. Ramig, and R.R. Allmaras. 1979. Field response of peas (Pisum sativum L.) to precipitation and temperature. J. Amer. Soc. Hort. Sci. 104:548-550.

Ridge, P.E. and D.L. Rye. 1985. The effects of temperature and frost at flowering on the yield of peas grown in a Mediterranean environment. Field Crops Res. 12:339-346.

Snedecor, G.W. and W.G. Cochran. 1967. Statistical methods. The Iowa University Press, Ames. 6th ed. p. 419-420.

Stanfield, B., D.P. Ormrod, and H.F. Fletcher. 1966. Response of peas to environment. II. Effects of temperature in controlled environment cabinets. Can. J. Plant Sci. 46: 195-203.

Wang, J.Y. 1960. A critique of the heat unit approach to plant response studies. Ecology 41:785-790.

Wang, J.Y. 1962. The influence of seasonal temperature ranges on pea production. Proc. Amer. Soc. Hort. Sci. 80:436-448. 